heavy water, the marked components are better resolved, the first component with Raman frequency 2,394 being nearly of the same intensity as the second, whereas for ordinary water, the first component is not only not well resolved from the second, but is also less intense.

With the view of ascertaining the cause of this difference, the changes with temperature in the relative intensities of the three components for heavy water were investigated. The results revealed, in general, a similarity in the changes for the two kinds of water, but the structure of the band for heavy water at any temperature is analogous to that for ordinary water at a lower temperature. Owing to the extreme diffuseness of the bands, it is difficult to determine the exact values of the corresponding temperatures.

If these components are attributed to different polymers, namely, single, double and triple molecules $^{1}$, the difference in the relative intensities of the components for the two types of water at the same temperature indicates a difference in the relative proportions of their polymers. The similarity in the structure of the band for heavy water at any tem. perature to that of ordinary water at a lower tem. perature leads to the conclusion that characteristic temperatures for heavy water should be higher than for its isotopic analogue. This observation is confirmed from experiment, the temperatures of freezing, maximum density and boiling being $3 \cdot 8^{\circ}, 11 \cdot 6^{\circ}$ and $101 \cdot 4^{\circ} \mathrm{C}$. respectively.

For heavy water, the component with the smallest frequency at $2,394 \mathrm{~cm}^{-1}$, which we attribute to $\left(\mathrm{D}_{2} \mathrm{O}\right)_{3}$, diminishes in intensity with increasing temperature, whereas the third component $(2,674$ $\mathrm{cm}^{-1}$ ) increases correspondingly, the central component attributed to $\left(\mathrm{D}_{2} \mathrm{O}\right)_{2}$ remaining almost unaltered. These results indicate that the equilibrium between the polymers changes with temperature as for ordinary water.
Andhra University, Waltair.
Dec. 23.
${ }^{1}$ NATURE, 132, 480 (1933).
2 Proc. Roy. Soc., A, 145, 489 (1934).
- Wood, R. W., Phys. Rev., 45, 392 (1934).
-Ananthakrishnan, R., Proc. Ind. Acad. Sci., 2, 291 (1935).
s Bauer and Magat, C.R., 201, 667 (1934).

\section{Ramakrishna Rao.}
P. Koteswaram.

\section{Ethnographical Museums}

RECENTLY, there has been a certain correspondence in the Press about the India Museum, and now the question has been ventilated in NATURE of January 29 (pp. 177, 193). Though, unfortunately, I have only the usual superficial knowledge of things Indian, may I discuss the wider point of view of archæology and ethnology in general ? These are, of course, one and the same, the latter being only the former in the present tense. This point is indeed made in the remark regretting "the present divorce of antiquity from historic times".

A museum is, or should be, a centre of teaching and study, where everyone should have facilities for acquiring knowledge and broadening his interests in mankind according to his ability. This, of course, means teaching for the serious student, and general information for the vaguely interested public.

Coming back to the particular case in point, we may notice that the purpose of the Victoria and Albert
Museum, of which the India Museum is a section, is "to promote the application of art to manufactures". Yet I have noticed that it is Indian 'art' that is so much mentioned in the recent correspondence. Is all the emphasis once again to be laid on 'art' to the detriment of 'industry'?

Alas, after literature, art has formed the greatest obstacle with which the new study of man's accom. plishment has had to contend. All the world over, whether in ancient Egypt, in China, in the Muslim world, or in Europe, the approach to the past has always been primarily through an appreciation of the written word. Later has come an appreciation of the beautiful works of the past. It is only within the last fifty years or more that the new study of archæology and ethnology has grown up. That is a study of all the phenomena of any given civilization-not only of the things beautiful, but also of those that never aspired to beauty or sank into ugliness, but were merely made for everyday use.

The studies of literature and of art have been firmly entrenched in man's mind for many hundreds of years, and have produced their own splendid results. Hence, many find difficulty in discerning the new science. Then, if it begins to dawn upon them, they are liable to look upon it merely as an aberration of those who are not good enough to scale the heights of the others. It should, however, stand forth clearly as the independent line of study which it is, with its own methods and leading to its own results, just as do the other two.

Neither art nor literature is the whole of man's activities, but each is a part of them, just as much as the industries of flint-working, potting, weaving, carpentry, mechanics or any other.

Hence a museum should not be, as it used to be, a collection of things quaint or curious, or even of a few superlatively beautiful ones. It should, on the contrary, give a comprehensive view of a people's complete activities, good, bad and indifferent. These activities cannot be studied properly without reference to those of surrounding countries. Fortunately, an understanding of this has been growing recently. It is now many years since Sir Flinders Petrie began clamouring for a central institution which would cater for this sort of thing, and only last year a prize was offered for an essay treating of Egyptian archæology on these lines.

Finally, it may be remarked that an attractive display of objects will always appeal to people, whereas a learned treatise will only repel the majority.

\section{G. A. WAINWRIGHT}

(Late Inspector-in-Chief, Antiquities Department, Egypt).

26 Elm Park Gardens, London, S.W.10.

Feb. 2.

\section{Solubility of Cellulose in Water}

Pure cellulose is generally regarded as being perfectly insoluble in water, but experiments recently carried out in this laboratory indicate that pure cellulose is slightly soluble in pure water.

High-grade bleached commercial grades of cellulose contain water-soluble impurities (both organic and inorganic), usually less than 1 per cent. This watersoluble extract is determined by digesting a weighed sample of the cellulose for 2 hours on a water-bath 